\title{
PEROPERATIVE AND POSTOPERATIVE SHIVERING CONTROL BY ONDANSETRON AND OPIOIDS FOLLOWING SPINAL ANAESTHESIA- A CLINICAL COMPARATIVE STUDY
}

\author{
Ravi Kumar Goel1, Pratibha Jain Shah², Omprakash Sundrani³, Durga Shankar Patel4, Jaya Lalwani5, Kamal Kishore Sahare ${ }^{6}$
}

${ }_{1}^{1}$ Assistant Professor, Department of Anaesthesiology and Critical Care, Raipur Institute of Medical Sciences, Raipur, Chhattisgarh, India.

2Professor and HOD, Department of Anaesthesiology and Critical Care, Pt. JNM Medical College, Raipur, Chhattisgarh, India. ${ }_{3}^{3}$ Associate Professor, Department of Anaesthesiology and Critical Care, Pt. JNM Medical College, Raipur, Chhattisgarh, India. ${ }^{4}$ Associate Professor, Department of Anaesthesiology and Critical Care, Government Medical College, Ambikapur, Chhattisgarh, India. 5 Professor, Department of Anaesthesiology and Critical Care, Pt. JNM Medical College, Raipur, Chhattisgarh, India.

${ }^{6}$ Professor and HOD, Department of Anaesthesiology and Critical Care, Government Medical College, Rajnandgaon, Chhattisgarh, India.

\section{ABSTRACT}

\section{BACKGROUND}

Shivering occurs as an adverse effect of surgical procedures during regional anaesthesia. Numerous pharmacological interventions have been proposed for the prevention and treatment of shivering. The mechanism of the antishivering effect of these drugs has not yet been completely clearly understood.

The present study will therefore evaluate and compare the efficacy of IV administration of Ondansetron and Opioids (Fentanyl, Tramadol and Pentazocine) in controlling of peroperative and postoperative shivering after spinal anaesthesia.

\section{MATERIALS AND METHODS}

This is a prospective, randomised, double-blind controlled study. 120 patients between 18 - 60 years of age of ASA grade I and II of either sex undergoing lower limb or lower abdominal surgery were included in this study.

\section{RESULTS}

We observed that the mean pulse rate, systolic and diastolic blood pressure in all the 4 groups were within normal limits and there was no statistically significant difference among the groups. Our study revealed that Ondansetron, Pentazocine, Tramadol and Fentanyl were found to be effective in preventing and reducing the severity of shivering following Spinal Anaesthesia, but Ondansetron was less effective than Opioids.

\section{CONCLUSION}

Based on our experience in the present study, we conclude that tramadol is an ideal intravenous drug for intraoperative and postoperative control of shivering following Spinal Anaesthesia.

\section{KEY WORDS}

Spinal Anaesthesia, Shivering, Pentazocine, Tramadol, Fentanyl, Ondansetron.

HOW TO CITE THIS ARTICLE: Goel RK, Shah PJ, Sundrani 0, et al. Peroperative and postoperative shivering control by ondansetron and opioids following spinal anaesthesia- a clinical comparative study. J. Evolution Med. Dent. Sci. 2018;7(24):28422846, DOI: $10.14260 /$ jemds/2018/641

\section{BACKGROUND}

Shivering occurs as an adverse effect of surgical procedures during regional anaesthesia. It interferes with monitoring of ECG, blood pressure and oxygen saturation. It also increases $\mathrm{O}_{2}$ consumption, $\mathrm{CO}_{2}$ production, lactic acidosis, defective platelet function, wound infection, poor wound healing, increased blood pressure and heart rate. Shivering can be characterised by its threshold (Triggering core temperature), gain (Incremental intensity increase) and maximum intensity. During regional anaesthesia autonomic and behavioural thermoregulation are impaired, so vasoconstriction and shivering threshold are comparably decreased.

'Financial or Other Competing Interest': None.

Submission 13-02-2018, Peer Review 28-05-2018,

Acceptance 02-06-2018, Published 11-06-2018.

Corresponding Author:

Dr. Omprakash Sundrani,

Associate Professor

Department of Anaesthesiology and Critical Care,

Pt. JNM Medical College, Raipur, Chhattisgarh, India.

E-mail: sundraniop@rediffmail.com

DOI: $10.14260 /$ jemds $/ 2018 / 641$

\section{(c) $($ ) $९$}

The shivering threshold is reduced approximately by $1^{\circ} \mathrm{C}$, but the vasoconstriction threshold remains relatively normal. Such divergence between the shivering and vasoconstriction threshold is an unusual pattern of thermoregulatory impairment. It suggests that mechanism of thermoregulatory impairment during regional anaesthesia may be especially complexed.

Numerous pharmacological interventions have been proposed for the prevention and treatment of shivering. The mechanism of the anti-shivering effect of these drugs has not yet been completely cleared. Tramadol has a weak agonist action at opioid receptors and has serotonin reuptake inhibition property. Fentanyl is a pure $\mu$ agonist, pentazocine is a partial agonist- antagonist at opioid receptors. On the other hand, drugs having antagonistic action on serotonin-3 receptors like Ondansetron, Dolasetron and Granisetron also have antishivering property.

For these controversies, the present study will therefore evaluate and compare the efficacy of IV administration of Ondansetron and Opioids (Fentanyl, Tramadol and Pentazocine) in control of peroperative and postoperative shivering after spinal anaesthesia. 


\section{Aims and Objectives}

1. To compare the efficacy of IV administration of Opioids (Fentanyl, Tramadol, Pentazocine) and Ondansetron in preventing the incidence and severity of peroperative and postoperative shivering following spinal anaesthesia.

2. To compare the effect of drugs on $\mathrm{O}_{2}$ saturation, pulse rate, blood pressure and respiration, peripheral and core temperature.

3. To assess side effects/ complications related to the drug given.

\section{MATERIALS AND METHODS}

This is a prospective, randomised, double-blind controlled study. After obtaining Institutional Ethical Committee approval and caregiver written informed consent, 120 patients between 18 - 60 years of age of ASA grade I and II of either sex undergoing lower limb or lower abdominal surgery were included in this study.

Patients having pyrexial illness, allergy to study drugs, suffering from major illness including thyroid disease, hypertension, diabetes mellitus etc. and with any contraindication for spinal anaesthesia were excluded from the study.

Sample size was taken conveniently.

After a detailed history, general and systemic examination and necessary investigations, patients were randomised using a computerised randomisation table and allocated-

Group A- (40 patients) received IV Ondansetron $0.15 \mathrm{mg} / \mathrm{kg}$

Group B- (40 patients) received IV Pentazocine $0.5 \mathrm{mg} / \mathrm{kg}$

Group C- (40 patients) received IV Tramadol $1 \mathrm{mg} / \mathrm{kg}$

Group D- (40 patients) received IV Fentanyl $0.001 \mathrm{mg} / \mathrm{kg}$

All the studied drugs were administered intravenously 3 5 minutes prior to spinal anaesthesia randomly. After securing IV access with 18-G intracath, all patients were preloaded with $500 \mathrm{~mL}$ ringer lactate warmed at $37^{\circ} \mathrm{C}$. Noninvasive monitors viz. (ECG, NIBP, Pulse oximeter) were attached and vital parameters like heart rate, blood pressure, oxygen saturation, respiratory rate, core and peripheral temperature were continuously monitored and recorded preoperatively and at every 5 minutes for first 30 minutes and thereafter at every 15 minutes interval up to 2 hours after spinal anaesthesia. Core temperature was monitored by temperature probe T1 for nasopharynx and T2 for axillary skin and connected to multipara monitor.

All the patients were monitored for side effects like pruritus, nausea, vomiting, respiratory depression, bradycardia and hypotension.

Under all aseptic precautions, lumbar puncture was performed with 23-Gauge Quincke's type lumbar puncture needle in the L3-L4 interspace. After obtaining clear and free flow of CSF, Inj. Bupivacaine 0.5\% (heavy) $4 \mathrm{cc}$ was injected. After spinal injection, patients were placed supine and a sensory block up to T6 was obtained.

During anaesthesia $\mathrm{O}_{2}-3 \mathrm{~L} / \mathrm{min}$ was given and patients were covered with drapes, but not actively warmed. All fluids were warmed to $37^{\circ} \mathrm{C}$. The operating room temperature was maintained at $22-24^{\circ} \mathrm{C}$.
Time of occurrence of shivering was recorded and graded with a scale described by Crossley and Mahajan.

Grade 0- No Shivering.

Grade 1- Piloerection of peripheral vasoconstriction, but no visible shivering.

Grade 2- Muscular activity in one muscle group.

Grade 3- Muscular activity in more than one muscle group.

Grade 4- Shivering involving the whole unblocked body.

Hypotension was defined as systolic blood pressure $20 \%$ below the basal level.

Bradycardia was defined as heart rate less than 60 beats/min.

All the observations were recorded and tabulated and all the data were stored on disk and analysed with SPSS (Version 13.0, SPSS Inc., Chicago, IL) statistical software. The male/female distribution between the groups was compared using Chi-square test. Demographic data, blood pressure and heart rate data were compared between the groups using the two-tailed student's test. The quantitative data were expressed as mean (Standard deviation). Results were analysed statistically by two-way repeated measure ANOVA test. A p-value less than 0.05 was considered.

On the basis of results obtained and statistical evaluation, inference was drawn.

\section{RESULTS}

In our study, maximum number of patients had a sensory block level of T6 (70\%). Rest $30 \%$ of patients had a sensory block level of T5 or T7.

Mean time of surgical regression was $126 \pm 9.06$ mins, $120.5 \pm 12.12$ mins, $128 \pm 8.99$ mins and $126.16 \pm 9.06$ mins in Group A, B, C and D, respectively. There was no statistically significant differences among the groups with respect to time of sensory regression.

\begin{tabular}{|c|c|c|c|c|c|c|c|c|}
\hline \multirow{2}{*}{$\begin{array}{c}\text { Time } \\
\text { (mins) }\end{array}$} & \multicolumn{2}{|c|}{ Group-A } & \multicolumn{2}{c|}{ Group-B } & \multicolumn{2}{c|}{ Group-C } & \multicolumn{2}{c|}{ Group-D } \\
\cline { 2 - 9 } & Mean & SD & Mean & SD & Mean & SD & Mean & SD \\
\hline Pre-SAB & 83 & 11 & 84 & 10 & 84 & 11 & 83 & 10 \\
\hline 5 & 84 & 12 & 83 & 12 & 84 & 11 & 82 & 12 \\
\hline 10 & 82 & 13 & 83 & 13 & 83 & 13 & 83 & 11 \\
\hline 15 & 82 & 13 & 82 & 14 & 83 & 14 & 82 & 11 \\
\hline 20 & 82 & 14 & 82 & 14 & 84 & 14 & 81 & 13 \\
\hline 25 & 81 & 12 & 81 & 13 & 81 & 13 & 80 & 13 \\
\hline 30 & 79 & 13 & 81 & 12 & 81 & 12 & 79 & 12 \\
\hline 45 & 79 & 12 & 82 & 11 & 81 & 11 & 79 & 9.9 \\
\hline 60 & 80 & 11 & 82 & 10 & 81 & 11 & 79 & 9.5 \\
\hline 75 & 79 & 10 & 82 & 9.4 & 80 & 9.7 & 79 & 8.5 \\
\hline 90 & 79 & 9.1 & 81 & 8.6 & 80 & 8.9 & 77 & 8.3 \\
\hline 105 & 78 & 9 & 81 & 7.8 & 80 & 7.7 & 78 & 7.8 \\
\hline 120 & 78 & 8.1 & 80 & 7.2 & 79 & 7.3 & 78 & 7.9 \\
\hline Mean & 80 & 1.83 & 82 & 0.84 & 81 & 1.6 & 80 & 1.78 \\
\hline Table 1. Mean Pulse Rate at various Time Intervals \\
\hline
\end{tabular}

Table- 1 shows mean pulse rate at various time intervals. Mean pulse rate throughout the procedure was $80 / \mathrm{min}$, $82 / \mathrm{min}, 81 / \mathrm{min}$ and $80 / \mathrm{min}$ in Group A, B, C and D respectively. 


\begin{tabular}{|c|c|c|c|c|}
\hline $\begin{array}{c}\text { Significance } \\
\text { Test }\end{array}$ & $\begin{array}{c}\text { Group } \\
\text { A and B }\end{array}$ & $\begin{array}{c}\text { Group } \\
\text { B and C }\end{array}$ & $\begin{array}{c}\text { Group } \\
\text { C and D }\end{array}$ & $\begin{array}{c}\text { Group } \\
\text { D and A }\end{array}$ \\
\hline P-value & $>0.05$ & $>0.05$ & $>0.05$ & $>0.05$ \\
\hline
\end{tabular}

There was no statistically significant differences among the groups regarding pulse rate.

\begin{tabular}{|c|c|c|c|c|c|c|c|c|}
\hline $\begin{array}{c}\text { Time } \\
\text { Interval }\end{array}$ & Group-A & Group-B & \multicolumn{2}{c|}{ Group-C } & \multicolumn{2}{c|}{ Group-D } \\
\hline Mre-SAB & 119 & SD & Mean & SD & Mean & SD & Mean & SD \\
\hline 5 & 106 & 7.6 & 119 & 7.8 & 120 & 8.1 & 109 & 7.8 \\
\hline 10 & 102 & 7.9 & 103 & 6.6 & 110 & 8.1 & 107 & 9.2 \\
\hline 15 & 102 & 7.9 & 103 & 6.4 & 103 & 7.1 & 103 & 7.1 \\
\hline 20 & 102 & 7.6 & 103 & 6.5 & 103 & 7.1 & 103 & 6.9 \\
\hline 25 & 104 & 7.8 & 105 & 5.7 & 105 & 6.3 & 104 & 6.9 \\
\hline 30 & 105 & 7.7 & 106 & 5.7 & 107 & 6.1 & 106 & 5.7 \\
\hline 45 & 106 & 7.7 & 107 & 6.1 & 108 & 6.8 & 108 & 5.8 \\
\hline 60 & 107 & 7.1 & 108 & 6.0 & 108 & 6.6 & 108 & 5.5 \\
\hline 75 & 107 & 7.5 & 108 & 6.3 & 109 & 6.3 & 108 & 5.9 \\
\hline 90 & 108 & 6.9 & 110 & 6.1 & 111 & 6.4 & 111 & 5.8 \\
\hline 105 & 109 & 7.1 & 112 & 5.5 & 112 & 5.7 & 111 & 5.1 \\
\hline 120 & 111 & 10 & 113 & 6.0 & 114 & 5.6 & 113 & 5.3 \\
\hline Mean SBP & 106.414 .42 & 107.75 & 4.38 & 108.41 & 4.55 & 107.58 & 4.40 \\
\hline Table 2. Mean Systolic Blood Pressure at various Time \\
Intervals
\end{tabular}

Table- 2 shows mean systolic pressure at various time intervals. Mean systolic blood pressure throughout the procedure was $106.41 \pm 4.4 \mathrm{mmHg}, 107.75 \pm 4.38 \mathrm{mmHg}$, $108.41 \pm 4.55 \mathrm{mmHg}$ and $107.58 \pm 4.38 \mathrm{mmHg}$ in Group A, B, $\mathrm{C}$ and $\mathrm{D}$ respectively.

\begin{tabular}{|c|c|c|c|c|}
\hline $\begin{array}{c}\text { Significance } \\
\text { Test }\end{array}$ & $\begin{array}{c}\text { Group A } \\
\text { and B }\end{array}$ & $\begin{array}{c}\text { Group B } \\
\text { and C }\end{array}$ & $\begin{array}{c}\text { Group C } \\
\text { and D }\end{array}$ & $\begin{array}{c}\text { Group D } \\
\text { and A }\end{array}$ \\
\hline P-value & $>0.05$ & $>0.05$ & $>0.05$ & $>0.05$ \\
\hline
\end{tabular}

There was no statistically significant differences among the groups regarding systolic blood pressure.

\begin{tabular}{|c|c|c|c|c|c|c|c|c|}
\hline \multirow{2}{*}{$\begin{array}{c}\text { Time } \\
\text { (Min) }\end{array}$} & Group A & \multicolumn{2}{|c|}{ Group B } & \multicolumn{2}{c|}{ Group C } & \multicolumn{2}{c|}{ Group D } \\
\hline Pre-SAB & 76 & 6.7 & 77 & 7.1 & 77 & 6.6 & 77 & 6.5 \\
\hline 5 & 68 & 6.3 & 69 & 6.3 & 68 & 5.9 & 68 & 5.9 \\
\hline 10 & 66 & 6.7 & 66 & 6.7 & 67 & 6.6 & 68 & 6.1 \\
\hline 15 & 67 & 6.4 & 67 & 6.5 & 68 & 6.1 & 69 & 5.2 \\
\hline 20 & 69 & 5.7 & 70 & 4.9 & 70 & 5.3 & 70 & 4.9 \\
\hline 25 & 69 & 5.2 & 70 & 4.1 & 71 & 4.0 & 71 & 4.5 \\
\hline 30 & 69 & 5.2 & 70 & 4.1 & 70 & 4.0 & 71 & 4.8 \\
\hline 45 & 70 & 5.6 & 72 & 3.8 & 72 & 4.8 & 71 & 4.8 \\
\hline 60 & 71 & 5.2 & 72 & 3.8 & 72 & 4.8 & 70 & 4.1 \\
\hline 75 & 71 & 5.1 & 72 & 3.8 & 72 & 4.8 & 73 & 4.1 \\
\hline 90 & 72 & 4.6 & 72 & 4.1 & 72 & 4.8 & 72 & 4.5 \\
\hline 105 & 72 & 4.8 & 72 & 4.1 & 72 & 4.8 & 73 & 4.7 \\
\hline 120 & 72 & 4.3 & 72 & 4.1 & 72 & 4.3 & 73 & 4.7 \\
\hline Mean & 70 & 2.54 & 70.72 & 2.71 & 70.91 & 2.53 & 71.25 & 2.38 \\
\hline Table 3. Mean Diastolic Blood Pressure at Various Time \\
\hline \multicolumn{8}{|c|}{ Interval } \\
\hline
\end{tabular}

Table 3 shows mean diastolic blood pressure at various time interval in different groups. Mean diastolic pressure was $70 \pm 2.54 \mathrm{mmHg}, 70.72 \pm 2.71 \mathrm{mmHg}, 70.91 \pm 2.53 \mathrm{mmHg}$ and $71.25 \pm 2.38 \mathrm{mmHg}$ in Group A, B, C and D respectively.

\begin{tabular}{|c|c|c|c|c|}
\hline $\begin{array}{c}\text { Significance } \\
\text { Test }\end{array}$ & $\begin{array}{c}\text { Group } \\
\text { A and B }\end{array}$ & $\begin{array}{c}\text { Group } \\
\text { B and C }\end{array}$ & $\begin{array}{c}\text { Group } \\
\text { C and D }\end{array}$ & $\begin{array}{c}\text { Group } \\
\text { D and A }\end{array}$ \\
\hline P-value & $>0.05$ & $>0.05$ & $>0.05$ & $>0.05$ \\
\hline
\end{tabular}

There was no statistical difference among groups regarding diastolic blood pressure.

Mean respiratory rate was $16.02 \pm 0.27$ per min, $16 \pm 0$ per min, $16.25 \pm 0.82$ per min and $15.16 \pm 0.37$ per min in Group A, B, C and D respectively and there was no statistical difference among groups regarding respiratory rate.

Mean SPO2 was $99.58 \pm 0.49,99.83 \pm 0.37,99.75 \pm$ 0.43 and $99.58 \pm 0.49$ in Group A, B, C and D respectively and the difference was statistically insignificant.

\begin{tabular}{|c|c|c|c|c|c|c|c|c|}
\hline \multirow{2}{*}{$\begin{array}{c}\text { Time } \\
(\mathbf{m i n})\end{array}$} & \multicolumn{2}{|c|}{ Group A } & \multicolumn{2}{c|}{ Group B } & \multicolumn{2}{c|}{ Group C } & \multicolumn{2}{c|}{ Group D } \\
\cline { 2 - 9 } & Mean & SD & Mean & SD & Mean & SD & Mean & SD \\
\hline Pre-SAB & 36.6 & 0.1 & 36.6 & 0.07 & 36.5 & 0.1 & 36.6 & 0.09 \\
\hline 5 & 36.6 & 0.09 & 36.6 & 0.1 & 36.6 & 0.08 & 36.6 & 0.11 \\
\hline 10 & 36.4 & 0.1 & 36.4 & 0.15 & 36.4 & 0.11 & 36.4 & 0.11 \\
\hline 15 & 36.2 & 0.11 & 36.2 & 0.16 & 36.2 & 0.16 & 36.3 & 0.11 \\
\hline 20 & 36.1 & 0.13 & 36 & 0.2 & 36.1 & 0.2 & 36.2 & 0.11 \\
\hline 25 & 36 & 0.2 & 35.9 & 0.25 & 36 & 0.25 & 36.1 & 0.16 \\
\hline 30 & 35.9 & 0.21 & 35.8 & 0.26 & 35.9 & 0.28 & 35.9 & 0.21 \\
\hline 45 & 35.8 & 0.22 & 35.7 & 0.26 & 35.7 & 0.27 & 35.8 & 0.22 \\
\hline 60 & 35.7 & 0.24 & 35.6 & 0.27 & 35.6 & 0.27 & 35.7 & 0.24 \\
\hline 75 & 35.5 & 0.25 & 35.5 & 0.27 & 35.5 & 0.28 & 35.6 & 0.24 \\
\hline 90 & 35.4 & 0.27 & 35.4 & 0.28 & 35.4 & 0.27 & 35.4 & 0.26 \\
\hline 105 & 35.4 & 0.27 & 35.3 & 0.29 & 35.4 & 0.28 & 35.4 & 0.260 \\
\hline 120 & 35.4 & 0.26 & 35.4 & 0.26 & 35.4 & 0.27 & 35.5 & 0.25 \\
\hline \multicolumn{8}{|c|}{ Table 4. Mean Peripheral Temperature $\left(^{\circ} \mathrm{C}\right)$} \\
\hline
\end{tabular}

Table- 4 shows mean peripheral temperature at various time interval in different groups. These show that there was a gradual fall in peripheral temperature after induction of anaesthesia. This fall in peripheral temperature was maximum during the first 30 mins. At the completion of two hour, the peripheral temperature was $35.4 \pm 0.26,35.4 \pm 0.26$, $35.4 \pm 0.27$ and $35.5 \pm 0.25^{\circ} \mathrm{C}$ in Group A, B, C and D respectively.

\begin{tabular}{|c|c|c|c|c|}
\hline $\begin{array}{c}\text { Significance } \\
\text { Test }\end{array}$ & $\begin{array}{c}\text { Group } \\
\text { A and B }\end{array}$ & $\begin{array}{c}\text { Group } \\
\text { B and C }\end{array}$ & $\begin{array}{c}\text { Group } \\
\text { C and D }\end{array}$ & $\begin{array}{c}\text { Group } \\
\text { D and A }\end{array}$ \\
\hline P-value & $>0.05$ & $>0.05$ & $>0.05$ & $>0.05$ \\
\hline
\end{tabular}

There was no statistical difference among groups regarding peripheral temperature.

\begin{tabular}{|c|c|c|c|c|c|c|c|c|}
\hline Time & \multicolumn{2}{|c|}{ Group A } & \multicolumn{2}{c|}{ Group B } & \multicolumn{2}{c|}{ Group C } & \multicolumn{2}{c|}{ Group D } \\
\cline { 2 - 9 } (Min) & Mean & SD & Mean & SD & Mean & SD & Mean & SD \\
\hline Pre-SAB & 37 & 0.09 & 37 & 0.08 & 37 & 0.09 & 37 & 0.1 \\
\hline 5 & 36.9 & 0.1 & 36.8 & 0.1 & 36.9 & 0.11 & 36.9 & 0.1 \\
\hline 10 & 36.7 & 0.11 & 36.7 & 0.12 & 36.7 & 0.14 & 36.7 & 0.11 \\
\hline 15 & 36.6 & 0.12 & 36.6 & 0.14 & 36.6 & 0.14 & 36.6 & 0.12 \\
\hline 20 & 36.5 & 0.14 & 36.5 & 0.15 & 36.5 & 0.16 & 36.5 & 0.13 \\
\hline 25 & 36.4 & 0.15 & 36.4 & 0.16 & 36.4 & 0.17 & 36.4 & 0.16 \\
\hline 30 & 36.3 & 0.19 & 36.3 & 0.2 & 36.3 & 0.2 & 36.3 & 0.18 \\
\hline 45 & 36.2 & 0.19 & 36.2 & 0.21 & 36.2 & 0.2 & 36.2 & 0.18 \\
\hline 60 & 36.1 & 0.21 & 36.1 & 0.22 & 36.1 & 0.21 & 36.1 & 0.2 \\
\hline 75 & 36 & 0.22 & 36 & 0.23 & 36 & 0.22 & 36 & 0.22 \\
\hline 90 & 35.9 & 0.25 & 35.9 & 0.26 & 35.9 & 0.24 & 35.9 & 0.24 \\
\hline 105 & 35.8 & 0.29 & 35.9 & 0.29 & 35.8 & 0.29 & 35.8 & 0.27 \\
\hline 120 & 35.8 & 0.31 & 35.9 & 0.3 & 35.9 & 0.31 & 35.9 & 0.28 \\
\hline Table 5. Mean Core Temperature at various Time Interval \\
\hline \multicolumn{10}{|c|}{}
\end{tabular}


Table- 5 shows mean core temperature at various time interval in different groups. These shows that there was a gradual fall in core temperature after induction of anaesthesia. The fall in core temperature was maximum during the first 30 mins. At the completion of two hours, the core temperature was $35.8 \pm 0.31,35.9 \pm 0.3,35.9 \pm 0.31$ and $35.9 \pm 0.28^{\circ} \mathrm{C}$ in Group A, B, C and D respectively.

\begin{tabular}{|c|c|c|c|c|}
\hline $\begin{array}{c}\text { Significance } \\
\text { Test }\end{array}$ & $\begin{array}{c}\text { Group } \\
\text { A and B }\end{array}$ & $\begin{array}{c}\text { Group } \\
\text { B and C }\end{array}$ & $\begin{array}{c}\text { Group } \\
\text { C and D }\end{array}$ & $\begin{array}{c}\text { Group } \\
\text { D and A }\end{array}$ \\
\hline P-value & $>0.05$ & $>0.05$ & $>0.05$ & $>0.05$ \\
\hline
\end{tabular}

There was no statistical difference among groups regarding core temperature.

\begin{tabular}{|c|c|c|c|c|}
\hline \multirow{2}{*}{$\begin{array}{c}\text { Shivering } \\
\text { Grade }\end{array}$} & Group-A & Group-B & Group-C & Group-D \\
\cline { 2 - 5 } & No. (\%) & No. (\%) & No. (\%) & No. (\%) \\
\hline Grade-I & $0(0 \%)$ & $1(3.33 \%)$ & $0(0 \%)$ & $0(0 \%)$ \\
\hline Grade-II & $3(10 \%)$ & $2(6.66 \%)$ & $1(3.33 \%)$ & $3(10 \%)$ \\
\hline Grade-III & $1(3.33 \%)$ & $0(0 \%)$ & $0(0 \%)$ & $0(0 \%)$ \\
\hline Grade-IV & $0(0 \%)$ & $0(0 \%)$ & $0(0 \%)$ & $0(0 \%)$ \\
\hline \multicolumn{6}{|c|}{ Table 6. Incidence and Grading of Shivering } \\
\hline
\end{tabular}

Table- 6 shows that incidence of shivering was least in Group C (3.33\%) as compared to $10 \%$ in Group B and D and $13.33 \%$ in Group A. None of the patients in Group B, C and D had shivering of Grade III and IV. Only one patient in Group A had shivering of Grade III.

\begin{tabular}{|c|c|c|c|c|}
\hline \multirow{2}{*}{ Time (Min) } & Group-A & Group-B & Group-C & Group-D \\
\cline { 2 - 5 } & No. & No. & No. & No. \\
\hline $21-30$ & $3(10 \%)$ & $0(0 \%)$ & $0(0 \%)$ & $1(3.33 \%)$ \\
\hline $31-40$ & $0(0 \%)$ & $1(3.33 \%)$ & $0(0 \%)$ & $0(0 \%)$ \\
\hline $41-50$ & $1(3.33 \%)$ & $2(6.66 \%)$ & $1(3.33 \%)$ & $2(6.66 \%)$ \\
\hline $51-60$ & $0(0 \%)$ & $0(0 \%)$ & $0(0 \%)$ & $0(0 \%)$ \\
\hline$>60$ & $0(0 \%)$ & $0(0 \%)$ & $0(0 \%)$ & $0(0 \%)$ \\
\hline \multicolumn{5}{|c|}{ Table 7. Time of occurrence of Shivering } \\
\hline
\end{tabular}

Table-7 shows that shivering if occurred was earlier in Group A (21-30 min) and incidence of shivering was also high in Group A. In Group B, C and D, time of occurrence of shivering was between $41-50$.

\begin{tabular}{|c|c|c|c|c|}
\hline $\begin{array}{c}\text { Duration } \\
\text { (Min) }\end{array}$ & Group A & Group B & Group C & Group D \\
\cline { 2 - 5 } & No. (\%) & No. (\%) & No. (\%) & No. (\%) \\
\hline Hypotension & $2(6.66 \%)$ & $0(0 \%)$ & $2(6.66 \%)$ & $1(3.33 \%)$ \\
\hline Bradycardia & $0(0 \%)$ & $0(0 \%)$ & $0(0 \%)$ & $1(3.33 \%)$ \\
\hline $\begin{array}{c}\text { Respiratory } \\
\text { depression }\end{array}$ & $0(0 \%)$ & $1(3.33 \%)$ & $1(3.33 \%)$ & $3(10 \%)$ \\
\hline Emetic episode & $0(0 \%)$ & $2(6.66 \%)$ & $1(3.33 \%)$ & $0(0 \%)$ \\
\hline Pruritus & $0(0 \%)$ & $0(0 \%)$ & $0(0 \%)$ & $3(10 \%)$ \\
\hline \multicolumn{5}{|c|}{ Table 8. Side Effect } \\
\hline
\end{tabular}

Table- 8 shows that incidence of hypotension was $2,0,2$ and 1 in Group A, B, C and D respectively. Incidence of bradycardia was nil among the groups. Incidence of respiratory depression was $3(10 \%)$ in Group D as compared to $0(0 \%), 1(3.33 \%)$ and $1(3.33 \%)$ in Group A, B, C and D respectively. Incidence of nausea and vomiting was found in 2 cases $(6.66 \%)$ in Group B only. Incidence of pruritus was found in 3 cases (10\%) in Group D.

\section{DISCUSSION}

The aim of the study was to compare ondansetron and opioids for control of peroperative and postoperative shivering following spinal anaesthesia.

All the four groups were comparable with respect to demographic profile, type and duration of surgery.

In our study maximum patients (70\%) had achieved a sensory block level up to T6 dermatomes. Maximum sensory block level was up to T5 (10\% patients) and minimum sensory block level was up to T7 dermatome (20\% patients).

In our study we observed that in maximum number of cases, time of sensory regression was in the range of 120-130 mins. Mean time of sensory regression was $126 \pm 9.06$ mins, $120.5 \pm 12.13$ mins, $128.66 \pm 8.99$ mins and $126.16 \pm 9.06$ mins in Group A, B, C, D respectively. The 4 groups were comparable to each other and there was no statistically significant difference among the groups ( $p>0.05$ ).

We observed that the mean pulse rate, systolic and diastolic blood pressure in all the 4 groups were within normal limits and there was no statistically significant difference among the groups.

Kurz A et al in $1995^{1}$ observed that intraoperative hypothermia has only mild effect on postoperative heart rate and blood pressure in relatively young healthy patients.

Bhatnagar S et al 20012 reported that there was no significant difference in pulse rate before and after IV administration of Tramadol and Pethidine for shivering control.

Trekova NA et al $2004^{3}$ reported that there was no significant change in heart rate and blood pressure after IV administration of Tramadol or placebo for shivering control.

Hasankhani $\mathrm{H}$ et al $2007^{4}$ observed that intraoperative IV fluids warming reduces perioperative changes in haemodynamic parameters and incidence of shivering.

Thus, our study was comparable to those of Kurz A et al 1995,1 Bhatnagar S et al 2001,2 Trekova NA et al $2004^{3}$ and Hasankhani $\mathrm{H}$ et al 2007.4 Mean respiratory rate throughout the procedure was around 16 per minute in all the four groups and SpO2 was $99 \%$ or above at all the times and there was no difference among the groups.

We observed that there was a gradual fall in peripheral and core temperature in all the four groups after induction of spinal anaesthesia. This fall was maximum during the first 30 minutes. Decrease was less in second hour as compared to first hour in all the four groups and there was no statistically significant difference in peripheral and core temperature among the groups at the end of two hours ( $p>0.05$ ).

De Witte JL et al $1998^{5}$ reported that Tramadol has only slight thermoregulatory effects and its use is unlikely to provoke hypothermia or to facilitate fever.

Robert M Powell et al $2000^{6}$ reported that Ondansetron 8 mg IV given during the induction of anaesthesia prevents post-anaesthetic shivering without affecting the core to peripheral redistribution of heat during general anaesthesia.

Ryu Komastsu et al $2006^{7}$ observed that Ondansetron did not reduce the shivering threshold in healthy volunteers.

Thus, our study was comparable to those of De Witte JL et al 19985, Robert M Powell et al $2000^{6}$ and Ryu Komastsu et al $2006 .^{7}$

We observed that incidence of shivering was least in Group C (3.33\%) as compared to Group B and D (10\%) and Group A (13.33\%). None of the patients in Group B, C and D 
had shivering of Grade III or IV. Only 1 patient in Group A had shivering of Grade III. Alfonsi P et al $1995^{\circ}$ reported that Fentanyl was $77 \%$ effective for shivering control.

Chan AM et al $1995^{\circ}$ concluded that IV Tramadol $0.5 \mathrm{mg}$ was effective for the treatment of intraoperative shivering during caesarean section without affecting newborn Apgar score. Terasako K et al $2000^{10}$ concluded that Pentazocine 7.5 mg IV had no significant role in post-anaesthetic shivering control, whereas Pethidine $17.5 \mathrm{mg}$ was significantly effective in shivering control.

Kelasaka et al $2001^{11}$ reported that Ondansetron and Meperidine were $92 \%$ effective in shivering control.

Trekova NA et al $2004^{3}$ reported that Tramadol was $98 \%$ effective in shivering control.

Sajedi P et al 200612 concluded that Meperidine, Alfentanyl, Sufentanyl, Fentanyl and Tramadol had a similar effect in the treatment of post-anaesthetic shivering.

Thus, our study was comparable to those of Alfonsi P et al 19958, Terasako $\mathrm{K}$ et al 200010, Kelasaka et al 200111, Trekova NA et al $2004^{3}$ and Sajedi P et al 2006.12

We observed that shivering if occurred was earlier in Group A (21 - 30 mins). In Group B, C and D time of occurrence of shivering was between 41 - 50 mins and the results of our study were comparable to that of Mucio Paranhos de Abreu et al 2002 who observed that there was a significant difference between Fentanyl and Placebo group in shivering occurrence at 60 mins and 90 mins interval after epidural block.

Incidence of hypotension was $6.66 \%, 0 \%, 6.66 \%$ and 3.335 in Group A, B, C and D respectively. Bradycardia was not observed in any of the cases. Mild respiratory depression was present in 3 cases in Group D and 1 case each in Group B and $\mathrm{C}$, which did not need any intervention. None of the patients in Group A had respiratory depression.

Nausea and vomiting were more commonly present in Group B (2 cases) as compared to Group A and D (0\%), whereas one patient in Group C complained of nausea. Mild pruritus was present only in Group D (3 cases).

Tsai YC et al $2001^{13}$ reported that incidence of somnolence was $7 \%$ with Tramadol and there was no significant difference in incidence of pruritus, nausea and vomiting as compared to placebo.

Mathews S et al $2002^{14}$ observed that tramadol $1-2 \mathrm{mg}$ for shivering control did not increase the incidence of sedation and vomiting.

Trekova NA et al $2004^{3}$ observed mild sedation in $17 / 50$ with the use of IV Tramadol $2 \mathrm{mg} / \mathrm{kg}$ for shivering control.

Sajedi $\mathrm{P}$ et al $2006^{12}$ observed that there was no significant difference in the incidence of pruritus, nausea vomiting and dizziness following IV administration of Fentanyl, Tramadol, Meperidine and Sufentanyl.

Thus, our study was comparable to those of Tsai YC et al $2001,{ }^{13}$ Mathews S et al 2002,14 Trekova NA et al 2004³ and Sajedi P et al 2006.12

\section{CONCLUSION}

Our study revealed that Ondansetron, Pentazocine, Tramadol and Fentanyl were found to be effective in preventing and reducing the severity of shivering following Spinal Anaesthesia, but Ondansetron was less effective than opioids.
Among the opioids, Fentanyl was associated with mild respiratory depression and pruritus. Nausea and vomiting were more common with pentazocine.

Based on our experience in the present study, we conclude that tramadol is an ideal intravenous drug for intraoperative and postoperative control of shivering following Spinal Anaesthesia.

\section{REFERENCES}

[1] Kurz A, Sessler DI, Narzt E, et al. Postoperative hemodynamic and thermoregulatory consequences of intraoperative core hypothermia. J Clin anesth 1995;7(5):359-66.

[2] Bhatnagar S, Saxena A, Kannan TR, et al. Tramadol for postoperative shivering: a double blind comparison with pethidine. Anesth Intensive Care 2001;29(2):149-54.

[3] Trekova NA, Buniaton AA, Zolicheva NIu. Tramadol in postspinal shivering in caesarean section. Anestesiol Reanimatol 2004;(5):86-9.

[4] Hasankhani H, Mohammadi E, Moazzami F, et al. The effects of intravenous fluids temperature on perioperative hemodynamic situation, postoperative shivering and recovery in orthopaedic surgery. Can Oper Room Nurs J 2007;25(1):20-4, 26-7.

[5] De Witte JL, Kim JS, Sessler DI, et al. Tramadol reduces the sweating, vasoconstriction and shivering thresholds. Anesth Analgesia 1998;87(1):173-9.

[6] Powell RM, Buggy DJ. Ondansetron given before induction of anesthesia reduces shivering after general anesthesia. Anesthesia Analgesia 2000;90(6):1423-7.

[7] Komatsu R, Orhan-Sungur M, In J, et al. Ondansetron does not reduce the shivering threshold in healthy volunteers. J Clin Anesth 2006;96(6):732-7.

[8] Alfonsi P, Hongnat JM, Lebrault $\mathrm{C}$, et al. The effects of pethidine, fentanyl and lidocaine on postanesthetic shivering. Anesthesia 1995;50(3):214-7.

[9] Chan AM, Ng KF, Tong EW, et al. Control of shivering under regional anesthesis in obstetric patients with tramadol. Can J Anesth 1999;46(3):253-8.

[10] Terasako K, Yamamoto M. Comparison between pentazocine, pethidine and placebo in the treatment of post-anesthetic shivering. Acta Anesthesiol Scand 2000;44(3):311-2.

[11] Kelasaka E, Baris S, Karakaya D, et al. Comparison of ondansetron and meperidine for prevention of shivering in patients undergoing spinal anesthesia. Reg Anesth Pain Med 2006;31(1):40-5.

[12] Sajedi P, Nazemroaya B. Comparing the effectiveness of antishivering action of meperidine, sufentanyl, alfentanyl and tramadol after general anesthesia. Shiraz E-Medical Journal 2006;7(3):1-6.

[13] Tsai YC, Chu KS. A Comparision of tramadol, amitripthyline and meperidine for postepidural anesthetic shivering in parturients. Anesth Analgesia 2001;93(5):1288-92.

[14] Mathews S, Al Mulla A, Varghese PK, et al. Postanesthetic shivering - a new look for Tramadol. Anesthesia 2002;57(4):394-8. 